\title{
Effect of Long-Term Paddy-Upland Yearly Rotations on Rice (Oryza sativa) Yield, Soil Properties, and Bacteria Community Diversity
}

\author{
Song Chen, ${ }^{1}$ Xi Zheng, ${ }^{2}$ Dangying Wang, ${ }^{1}$ Liping Chen, ${ }^{1}$ Chunmei Xu, ${ }^{1}$ and Xiufu Zhang1 \\ ${ }^{1}$ China National Rice Research Institute, Chinese Academy of Agricultural Sciences, Zhejiang, Hangzhou 310006, China \\ 2 985-Institute of Agrobiology and Environmental Sciences, Zhejiang University, Hangzhou 310029, China \\ Correspondence should be addressed to Song Chen, chais.zju@gmail.com
}

Received 30 May 2012; Accepted 17 June 2012

Academic Editors: H. P. Bais, L. E. Parent, and A. R. Garrigós

Copyright (C) 2012 Song Chen et al. This is an open access article distributed under the Creative Commons Attribution License, which permits unrestricted use, distribution, and reproduction in any medium, provided the original work is properly cited.

\begin{abstract}
A 10-year-long field trial (between 2001 and 2010) was conducted to investigate the effect of paddy-upland rotation on rice yield, soil properties, and bacteria community diversity. Six types of paddy-upland crop rotations were evaluated: rice-fallow (control; $\mathrm{CK})$, rice-rye grass (RR), rice-potato with rice straw mulches (RP), rice-rapeseed with straw incorporated into soil at flowering (ROF), rice-rapeseed incorporated in soil after harvest (ROM), and rice-Chinese milk vetch (RC). Analysis of terminal restriction fragment length polymorphism (T-RFLP) was used to determine microbial diversity among rotations. Rice yield increased for upland crops planted during the winter. RC had the highest average yield of $7.74 \mathrm{t} /$ ha, followed by RR, RP, ROM, and ROF. Soil quality differences among rotations were found. RC and RP improved the soil mean weight diameter (MWD), which suggested that rice rotated with milk vetch and potato might improve the paddy soil structure. Improved total nitrogen (TN) and soil organic matter (SOM) were also found in RC and RP. The positive relationship between yield and TN/SOM might provide evidence for the effect of RC rotation on rice yield. A strong time dependency of soil bacterial community diversity was also found.
\end{abstract}

\section{Introduction}

In China and other Asian countries, continuous rice planting has had a negative impact on soil properties, such as reduced soil nitrogen supply and organic carbon content $[1,2]$. Paddy-rice-upland crop rotations have been recommended and used to improve soil quality and reduce input [3-8].

In conventional paddy-upland rotation systems, farmers drain the fields after harvesting rice and then plant an upland crop, such as milk vetch, wheat, or oilseed [911]; However, the growth conditions required by rice are quite different from those required by upland crops. Rice will grow best under puddled, reduced, and anaerobic soil conditions, whereas upland crops require unpuddled, aerobic and oxidized soil conditions. Paddy soils show a large difference from upland soils in physical, chemical, and biological properties [12]. Furthermore, because of long-term submergence and mineral fertilizer application, paddy soils experience degradation of soil quality, such as breakdown of stable aggregation and deterioration of soil organic matter (SOM), which negatively affects agricultural sustainability $[13,14]$.

Soil quality is a term used to describe the health of agricultural soils. It has been suggested as an indicator for evaluating sustainability of soil and crop management practices [15-17]. Many soil attributes have been proposed to describe soil quality, but evaluation of $\mathrm{pH}$, soil organic matter (SOM), and total nitrogen content (TN) of soil have been considered essential for assessing the chemical aspects of soil quality $[15,17]$. These chemical traits are so important because they provide a measure of the ability of soil to supply nutrients and to buffer against chemical additives [18-20].

Soil physical properties are indicators of the impact of soil and crop management practices. Soil size distribution and water stability of soil aggregates would be influenced by crop types as well as soil management practices [21]. Furthermore, microbial populations in soil interact with each other and with soil. These interactions, in turn, affect 
major environmental processes, including biogeochemical cycling of nutrients, plant health, and soil quality [22]. Most microbial interactions in soil occur near the plant roots and the root-soil interface, called the rhizosphere [23, 24]. It is not surprising that microbial communities in the rhizosphere depend on plant species $[25,26]$. Although the relationships between soil microbial diversity and function and sustainability (or stability) of agricultural ecosystems are still unclear $[17,27,28]$, it has been documented that diversity of soil biota is important to the beneficial function of agro-ecosystems [29, 30].

In China, paddy-upland crop rotation is a major cropping system utilized along the Yangtze River basin [31-33]. Traditionally, the main patterns of rice and upland crop are rice-wheat, rice-oilseed, rice- milk vetch, and rice-ryegrass [4]. However, some practices may not be economical because of high input and increased risk of financial loss for the rice crop. Currently, new patterns including rice-oilseed rape (Brassica napus L.) and rice-potato (Solanum tuberosum) are widely used. However, few studies have been done to determine the effect of these paddy-upland crop rotations on soil physical and chemical properties. The present study was conducted to determine the effect of long-term cropping system on (i) rice and other crop yields, (ii) soil quality attributes (chemical and physical), and (iii) the diversity of soil bacterial community. The results offer helpful insight into the effect of various rice-upland combinations on crop productivity and soil properties.

\section{Materials and Methods}

2.1. Soil and Site. The study was conducted over a period of ten years at the experimental farm of the China Rice Research Institute (120.2 E, 30.3 N, and $11 \mathrm{~m}$ above sea level) located in Fuyang, Hangzhou, China. The long-term field experiment has been carried out in an irrigated rice paddy starting in 2001. The historical cropping background was monoculture rice cropping before this time. The area is characterized by a subtropical monsoon climate with an annual mean temperature of $13-20^{\circ} \mathrm{C}$, ranging from $2^{\circ} \mathrm{C}$ in January to $35^{\circ} \mathrm{C}$ in July and mean precipitation of 1200 $1600 \mathrm{~mm}$ per year, with about $80 \%$ falling between April and September. Soil is classified as Ferric-accumulic Stagnic Anthrosols [34] and entic Halpudept [35]. Further details about the experimental site can be found in the study of Fu et al. [36].

2.2. Experimental Design and Crop Cultivation. The longterm field experiment included six different types of cropping rotation: continuous monoculture rice-fallow (CK), rice-ryegrass (Lolium perenne) (RR), rice-potato (Solanum tuberosum) (RP), rice-Chinese milk vetch (Astragalus sinicus L.) (RC), rice-oilseed rape (Brassica napus L.) with burned straw returned to the soil after harvest (ROM), and riceoilseed rape with fresh oilseed straw returned as mulch at flowering (ROF). Primary tillage was followed by a pass of a stubble crushing machine to a depth of $0-20 \mathrm{~cm}$ about three days before rice seedling transplanting in early June every year. During the rice season, the rice species used was Guodao 6, an elite Japonica hybrid widely planted in Southeast China. Direct sowing was applied for seedling establishment, with a seeding rate of $15 \mathrm{~kg} / \mathrm{ha}$. The amount of fertilizer application was set according to local agronomic practices. It is noteworthy that there was a significant reduction in nitrogen input starting in 2005 due to the serious rice lodging of several rotations. The rate and timing of fertilizer was set as follows: basal application, including total phosphorous, $50 \%$ nitrogen, and 50\% potassium, was conducted a week before transplantation in the form of compound fertilizer; $25 \%$ nitrogen was applied as topdressing at mid-tillering in the form of urea, and $25 \%$ nitrogen and $50 \%$ potassium was applied as topdressing at panicle initiation in the form of urea and potassium chloride, respectively. Weeds, insects, and diseases were controlled as required to avoid yield loss. More details of the agronomic practice are presented in Table 1.

The field experiment was planned with a large plot area ( $20 \mathrm{~m}$ long, $20 \mathrm{~m}$ wide) but without treatment replicates due to practical reasons. Although this design could lead to statistical problems, the cropping system has been used for decades with uniform fertilizer management. The small variability $(\mathrm{CV}<5 \%)$ of the representative parameters of soil fertility in the treatment plots (Table 2) indicates a low spatial heterogeneity of the field. We therefore believe it is reasonable to assume that any significant differences later observed between plots were caused by the different rotations.

2.3. Sampling and Measurement. In 2010, a survey of rice yield was carried out as follows: hills were harvested from the uniform part of each plot of $5 \mathrm{~m}^{2}$ with 4 subsamples. Unhulled (rough) rice was obtained after reaping, threshing, and wind selection. Rough rice from 80 hills was hulled and then put through a $1.8 \mathrm{~mm}$ sieve to remove any immature kernels. The weight of hulled rice (brown rice) was adjusted to a moisture content of $14 \%$. Upland crop biomass was sampled from $1 \mathrm{~m}^{2}$ of four sub-sample plots. For RC, RP, ROM, and ROF, plants were sampled at harvest. For RR, sampling was carried on during the growth season. All samples were oven-dried at $70^{\circ} \mathrm{C}$ to a constant weight to determine the dry weight.

Soil samples from 0 to $20 \mathrm{~cm}$ depth at pretransplanting in early June 2010 were used for soil physical quality analysis. Bulk density was determined for undisturbed soil samples using a steel cylinder of $100 \mathrm{~cm}^{3}$ volume $(5 \mathrm{~cm}$ in diameter, and $5.1 \mathrm{~cm}$ in height) [37] Soil aggregation was determined by the wet sieving method [38]. The mean weight diameter was calculated as follows:

$$
\mathrm{MWD}=\sum_{i=1}^{n} X i W i
$$

where MWD is the mean weight diameter of water-stable aggregates, $X i$ is the mean diameter of each size fraction $(\mathrm{mm})$, and $W i$ is the proportion of the total sample mass in the corresponding size fraction after the mass of stones was deducted (upon dispersion and passing through the same sieve). 


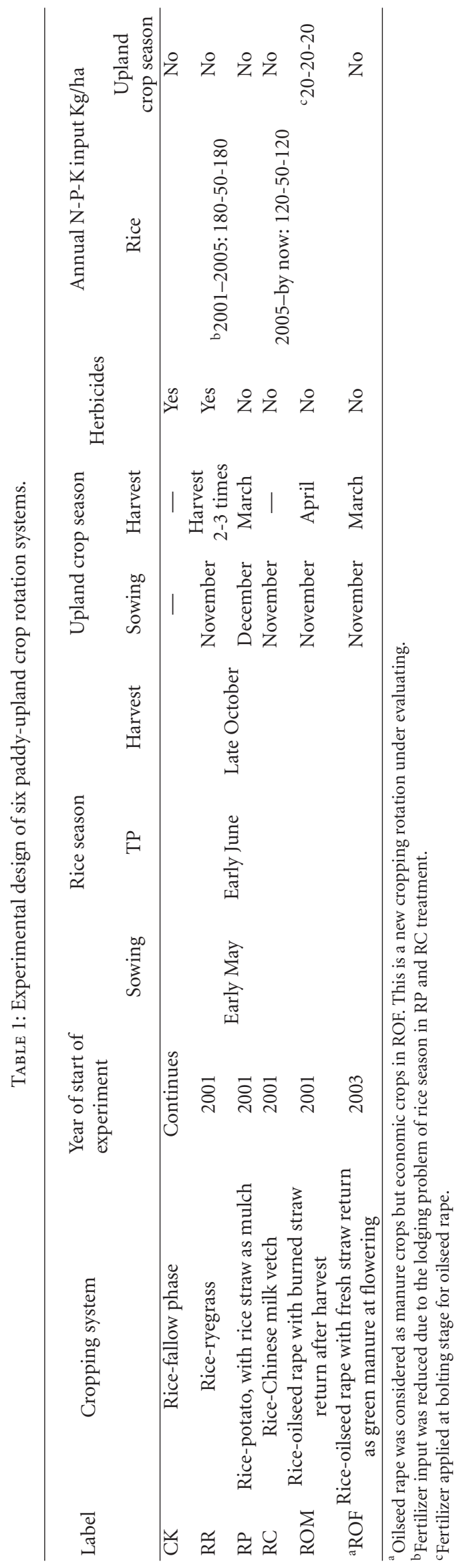


TABLE 2: General soil properties before the experiment started in $2001(0-20 \mathrm{~cm}$ soil depth).

\begin{tabular}{|c|c|c|c|c|c|c|}
\hline Treatment & $\mathrm{pH}$ & $\begin{array}{l}\text { SOM } \\
(\mathrm{g} / \mathrm{kg})\end{array}$ & $\begin{array}{c}\mathrm{TN} \\
(\mathrm{g} / \mathrm{kg}) \\
\end{array}$ & $\begin{array}{c}\mathrm{TP} \\
(\mathrm{g} / \mathrm{kg}) \\
\end{array}$ & $\begin{array}{c}\text { available K } \\
(\mathrm{g} / \mathrm{kg})\end{array}$ & $\begin{array}{c}\text { Bulk density } \\
\left(\mathrm{g} / \mathrm{cm}^{3}\right)\end{array}$ \\
\hline CK & 6.51 & 26.90 & 2.53 & 0.62 & 0.22 & 1.17 \\
\hline $\mathrm{RP}$ & 6.69 & 24.50 & 2.49 & 0.65 & 0.24 & 1.21 \\
\hline $\mathrm{RR}$ & 6.82 & 25.60 & 2.50 & 0.63 & 0.23 & 1.12 \\
\hline $\mathrm{RC}$ & 6.62 & 29.10 & 2.46 & 0.66 & 0.23 & 1.24 \\
\hline $\mathrm{ROM}$ & 6.43 & 27.50 & 2.69 & 0.61 & 0.22 & 1.11 \\
\hline ROF & - & - & - & - & - & - \\
\hline Means & 6.61 & 26.72 & 2.53 & 0.64 & 0.23 & 1.17 \\
\hline${ }^{\mathrm{b}} \mathrm{CV} \%$ & 2.30 & 4.81 & 3.32 & 3.08 & 3.61 & 4.85 \\
\hline
\end{tabular}

available $\mathrm{K}$ was extracted with $1 \mathrm{~mol} \mathrm{NH}_{4} \mathrm{AC}$.

${ }^{\mathrm{b}} \mathrm{C} . \mathrm{V}$. is coefficient of variation.

Abbreviations: CK: rice-fallow phase; RR: rice-ryegrass; RP: rice-potato, with rice straw as mulch; RC: rice-Chinese milk vetch; ROM: rice-oilseed rape with burned straw return after harvest; ROF: rice-oilseed rape with fresh straw return as mulch at flowering.

Soil samples for chemical analysis were collected at pretransplanting in early June 2010 from two depths (010 and $10-20 \mathrm{~cm})$. The field-moist soil samples were passed through an $8 \mathrm{~mm}$ sieve and air-dried. Cation exchange capacity (CEC) was measured according to the procedure used by Hendershot et al. [39]. Electrical conductivity was measured using a digital conductivity meter. Soil total N (TN) and total $\mathrm{P}$ were estimated by the methods given by Bremner and Mulvaney [40] and Sparling et al. [41], respectively. Soil water content was determined gravimetrically $\left(105^{\circ} \mathrm{C}, 24 \mathrm{~h}\right)$. Results were expressed based on the dry weight of the soil. Soil $\mathrm{pH}$ was determined (1:5 water suspension) by $\mathrm{pH}$ meter. Soil available potassium was determined by extraction with $1 \mathrm{~mol} \mathrm{NH}_{4} \mathrm{AC}$. Soil organic matter (SOM) was determined by a dichromate oxidation procedure. Multiplying the soil organic carbon by 1.72 resulted in the SOM [42]. The microbial biomass C (MBC) was determined using the chloroform fumigation-extraction method on fresh soils [43]. Each replicate was divided into two equivalent portions: one was fumigated for $24 \mathrm{~h}$ with ethanol-free chloroform and the other was not fumigated as a control. Both fumigated and unfumigated soils were shaken for $30 \mathrm{~min}$ with $0.5 \mathrm{M} \mathrm{K}_{2} \mathrm{SO}_{4}$ (1:4 soil : extraction ratio) and centrifuged and filtered. Extracts were analyzed for DOC on a total organic $\mathrm{C}$ analyzer (TOC-V CPH, Shimadzu).

Soil samples for T-RFLP analysis were collected from each plot using a soil auger $(5 \mathrm{~cm}$ in diameter $)$ at pretransplanting in early June 2010 (BR) and after harvest in late October 2010 (AR) from 0-20 cm soil depth. Samples were packed in sterile plastic bags and sent to the laboratory, then air-dried until the water content was about $75 \%$. Later, the moist soil was passed through a $2 \mathrm{~mm}$ sieve and stored at $4^{\circ} \mathrm{C}$ for DNA extraction.

2.4. DNA Extraction and T-RFLP Analysis. Genomic DNA of the soil samples was isolated using a SDS-hyperhaline buffer solution as used in Zhou et al. [44]. Approximately $1 \mathrm{~g}$ of dry soil was suspended in $2.7 \mathrm{~mL}$ of extraction buffer $(100 \mathrm{mM}$ Tris- $\mathrm{HCl}, 100 \mathrm{mM}$ EDTA, $100 \mathrm{mM} \mathrm{Na} \mathrm{PO}_{4}, 1.5 \mathrm{mM} \mathrm{NaCl}$,
$1 \% \mathrm{CTAB}, \mathrm{pH} 8.0)$, proteinase $\mathrm{K}(20 \mu \mathrm{L})$ was added, and the mixture was shaken at $225 \mathrm{rpm}$ at $37^{\circ} \mathrm{C}$ for $30 \mathrm{~min}$. The suspension was further incubated in $20 \%$ SDS at $65^{\circ} \mathrm{C}$ for $2 \mathrm{~h}$. During incubation, the tubes were gently frozen-thawed with liquid nitrogen for $20 \mathrm{~min}$ and run for three cycles. After that, the soil samples were centrifuged at 8,000 rpm for $10 \mathrm{~min}$ at $4^{\circ} \mathrm{C}$, followed by the extraction of supernatant with $2.6 \mathrm{~mL}$ chloroform-isoamyl alcohol $(24: 1)$ and centrifuged at $5,000 \mathrm{rpm}$ for $5 \mathrm{~min}$. The supernatant was precipitated for $2 \mathrm{~h}$ with $2 \mathrm{~mL}$ isopropanol before recovering the DNA with $10,000 \mathrm{rpm}$ centrifugation for $10 \mathrm{~min}$. The resulting pellet was washed with $2 \mathrm{~mL}$ of $70 \%$ (v/v) ice-cold ethanol, dried, and dissolved in $200 \mu \mathrm{L}$ of sterile distilled water. The purified DNA was stored at $4^{\circ} \mathrm{C}$ for at least 1 day before PCR amplification. Preliminary analysis showed that the heterogeneity of the profiles obtained from independent preparations of the same soil sample decreased after storing of the fresh DNA.

The eubacterial primers $8 \mathrm{f}$ ( $5^{\prime}$-AGAGTTTGATCCTGGCTCAG-3' $3^{\prime}$ labeled at the $5^{\prime}$ end with 6-carboxyfluorescein (6-FAM) and 926r (5'-CCGTCAATTCCTTTRAGTTT- $\left.3^{\prime}\right)$ were used to amplify approximately $920 \mathrm{bp}$ of the $16 \mathrm{~S}$ rRNA gene [45]. Each PCR reaction mixture $(25 \mu \mathrm{L})$ contained $2.5 \mu \mathrm{L} 10 \times$ TransTaq HiFi Buffer I $(200$ mM Tris- $\mathrm{HCl}(\mathrm{pH}$ 8.4), $\left.200 \mathrm{mM} \mathrm{KCl}, 100 \mathrm{mM}\left(\mathrm{NH}_{4}\right)_{2} \mathrm{SO}_{4}, 20 \mathrm{mM} \mathrm{MgCl}_{2}\right)$, $2 \mu \mathrm{L} 2.5 \mathrm{mM}$ dNTPs, $2 \mu \mathrm{L} 10 \mu \mathrm{M}$ primers, $0.5 \mu \mathrm{L} 5$ unit $\mu \mathrm{L}^{-1}$ of TransTaq polymerase High Fidelity (Beijing TransGen Biotech Co., Ltd. China), and $2 \mu$ L genomic DNA temples in a final volume of $25 \mu \mathrm{L}$. All amplifications were performed on a DNA Engine Dyad thermal cycler (Bio-Rad, Inc., USA) using the following program: a 5-min hot start at $94^{\circ} \mathrm{C}$, followed by 39 cycles consisting of denaturation ( $1 \mathrm{~s}$ at $94^{\circ} \mathrm{C}$ ), annealing $\left(45 \mathrm{~s}\right.$ at $50^{\circ} \mathrm{C}$ and $60^{\circ} \mathrm{C}$, resp.), and extension $\left(1 \mathrm{~min}\right.$ at $\left.72^{\circ} \mathrm{C}\right)$, with a final extension at $72^{\circ} \mathrm{C}$ for $10 \mathrm{~min}$. PCR products were detected using 1.0\% agarose gel electrophoresis in a $1 \times$ TAE buffer. Fluorescentlylabeled PCR products $(200 \mu \mathrm{L})$ were purified with a UNIQ10 DNA purification kit (Sangon Biotech Co., Ltd., China). Approximately $50 \mathrm{ng}$ of amplified 16S rRNA gene fragments 
was digested with HaeIII (GG'CC), HhaI $\left(\mathrm{GCG}^{\prime} \mathrm{C}\right)$, and HinfI ( $\left.\mathrm{G}^{\prime} \mathrm{ANTC}\right)$ for $4 \mathrm{~h}$ at $37^{\circ} \mathrm{C}$ and precipitated with isopropanol. The precipitated DNA was washed twice with $70 \%$ isopropanol, vacuum dried, and resuspended in $20 \mathrm{~mL}$ water. In the preliminary experiments, seven restriction enzymes (HaeIII, HhaI, Hinfl, MspI, AluI, and TaqI) were tested; the enzymes HhaI, Hinfl, and HaeIII had the higher yield. The sample was mixed with $0.1 \mathrm{~mL}$ of GeneScan 1000 Rox size standard, denatured at $95^{\circ} \mathrm{C}$ for $2 \mathrm{~min}$, immediately placed on ice, and evaluated following electrophoresis in POP6 polymer with an automated DNA sequencer (ABI 3100, Applied Biosystems Instruments, California, USA). Terminal fragment sizes between 29 and $940 \mathrm{bp}$ were determined using Gene-Mapper v3.7 software (Perkin-Elmer, California, USA).

2.5. Data Analysis. Data were analyzed by using Microsoft Excel 2003 and SAS 8.0 (2003). Means and standard deviations/standard errors are reported for each of the measurements. One-way analysis of variance (ANOVA) of Tukey's test was used to compare the effects of rotations on soil properties determined for the two soil depths of $0-10 \mathrm{~cm}$ and $10-20 \mathrm{~cm}$ separately.

All T-RFLP community profiles were labeled for statistical analyses by rotation (CK, RR, RP, RC, ROM, or ROF), sampling time (BR or AR), restriction enzyme (HaeIII, HhaI, or HinfI), and field plot replicate $(1,2$, or 3$)$. T-RF peaks between 35 and $500 \mathrm{bp}$ and peak heights of $<50$ fluorescence units were included in the analysis according to the range of the size marker. Generally, the error for determining fragment sizes with our automated DNA sequencer was less than $1 \mathrm{bp}$; however, in some cases, a higher variation was found. Therefore, T-RFs that differed by less than $1.5 \mathrm{bp}$ were clustered unless individual peaks were detected in a reproducible manner. Three replicate samples of all rotations and particle sizes were analyzed individually, or a representative sample profile was determined in a way similar to that suggested by Dunbar et al. [46]. Essentially, the sum of the peak heights in each replicate profile was calculated and used to indicate the total DNA quantity. Total fluorescence was adjusted to the medium DNA quantity by calculating a correction factor. For example, three replicate profiles had total fluorescence values of 4,500, 4,700, and 4,900 , and then each peak in the latter profile was multiplied by a factor of 0.96 (i.e., the quotient of 4,700/4,900), and peaks in the first profile were multiplied by a factor of 1.04 (i.e., a quotient of $4,700 / 4,500$ ). After adjustment, only peaks of $>50$ fluorescence units were considered. In addition, T-RFs were scored as positive only when they were present in at least two of the three replicates.

In order to determine similarities between T-RFLP profiles, a binary matrix that recorded the absence and presence of aligned fragments was generated. The distance matrix of fragments was generated according to the Jaccard index (1908) using NTSYS version 2.10e software for PC (Applied Biostatistics). Based on the distance matrix, cluster analysis was performed utilizing an unweighted pair group method with arithmetic average (UPGMA).
TABle 3: Soil physical properties in 0-20 $\mathrm{cm}$ depth.

\begin{tabular}{lccccc}
\hline Rotation & $\begin{array}{c}\text { a Sand } \\
(\mathrm{g} / \mathrm{kg})\end{array}$ & $\begin{array}{c}\text { Slit } \\
(\mathrm{g} / \mathrm{kg})\end{array}$ & $\begin{array}{c}\text { Clay } \\
(\mathrm{g} / \mathrm{kg})\end{array}$ & $\begin{array}{c}\text { MWD } \\
(\mathrm{mm})\end{array}$ & $\begin{array}{c}\text { Bulk density } \\
\left(\mathrm{g} / \mathrm{cm}^{3}\right)\end{array}$ \\
\hline CK & $40.9 \mathrm{~b}$ & 650.9 & $300.0 \mathrm{~b}$ & $0.07 \mathrm{~b}$ & $1.20 \mathrm{~b}$ \\
RC & $89.4 \mathrm{a}$ & 574.5 & $336.1 \mathrm{~b}$ & $0.11 \mathrm{a}$ & $1.39 \mathrm{a}$ \\
RR & $51.4 \mathrm{~b}$ & 559.2 & $389.4 \mathrm{a}$ & $0.08 \mathrm{~b}$ & $1.26 \mathrm{ab}$ \\
RP & $76.2 \mathrm{a}$ & 586.2 & $337.5 \mathrm{~b}$ & $0.10 \mathrm{a}$ & $1.21 \mathrm{~b}$ \\
ROM & $54.6 \mathrm{~b}$ & 551.5 & $393.9 \mathrm{a}$ & $0.08 \mathrm{~b}$ & $1.21 \mathrm{~b}$ \\
ROF & $42.6 \mathrm{~b}$ & 531.4 & $426.0 \mathrm{a}$ & $0.06 \mathrm{~b}$ & $1.35 \mathrm{a}$ \\
\hline
\end{tabular}

a Sand $2-0.05 \mathrm{~mm}$, silt $0.05-0.002 \mathrm{~mm}$, clay $<0.002 \mathrm{~mm}$.

Means on the same column and for the same sampling time followed by the same letter (or none) are not significantly different at $P<0.05$ by Tukey Test. Abbreviations: CK: rice-fallow phase; RR: rice-ryegrass; RP: ricepotato, with rice straw as mulch; RC: rice-Chinese milk vetch; ROM: riceoilseed rape with burned straw return after harvest; ROF: rice-oilseed rape with fresh straw return as mulch at flowering.

\section{Results}

3.1. Rice Yield and Upland Crops Biomass Production. Rice yield increased in the plots with upland crops applied during the winter season (Figure 1(a)). RC had the highest average yield of $7.74 \mathrm{t} / \mathrm{ha}$, which was $27.8 \%$ significantly higher than CK. No significant difference was observed among RR, RP, $\mathrm{ROM}$, and ROF, although their average yields were also higher than $\mathrm{CK}$, with average yield increase ranging from $14.2-17.8 \%$. Upland crop biomass production was estimated and is shown in Figure 1(b). RP had the highest average biomass production of $22.3 \mathrm{t} / \mathrm{ha}$, followed by ROF, RC, RR, and ROM. In CK, weeds grew and died during the fallow phase, making it difficult to estimate the biomass production due to the uneven growth of the weeds. As a result, no data are shown here to describe the biomass production in CK. Different from RP, RC, ROM, and ROF, biomass produced in $\mathrm{RR}$ was removed from the field as pasture crops. But all the plant residues in ROF, RP, and RC were returned to the field as cover crops and incorporated into soil before rice season. For ROM, the straw was burned after harvest and the ash was incorporated into soil by tillage. Generally speaking, RP had the highest value of biomass $C$ return, followed by $\mathrm{RC}$ and ROF. ROM and RR might have the lowest values next to CK.

3.2. Effect of Paddy-Upland Rotation System on Soil Properties. The soil bulk density, soil aggregation, and mean weight diameter (MWD) of different paddy-upland crop rotations are presented in Table 3 . The bulk density was significantly greater in RC and ROF than in the others, and RP and RC had relatively higher values of MWD compared with other rotations.

There was a strong depth-dependency of soil $\mathrm{pH}$ value, total soil nitrogen (TN), total soil phosphorus (TP), available potassium $(\mathrm{K})$, and cation exchange capacity (CEC) in all rotations (see Table 4). Soil was acid in all six rotations from $0-10 \mathrm{~cm}$ and $10-20 \mathrm{~cm}$ depth. However, the average $\mathrm{pH}$ value was significantly greater in $10-20 \mathrm{~cm}(5.90)$ than in $0-10 \mathrm{~cm}$ (5.44). In comparison with $\mathrm{CK}$, the $\mathrm{pH}$ values in $\mathrm{RC}$, $\mathrm{ROF}$, 


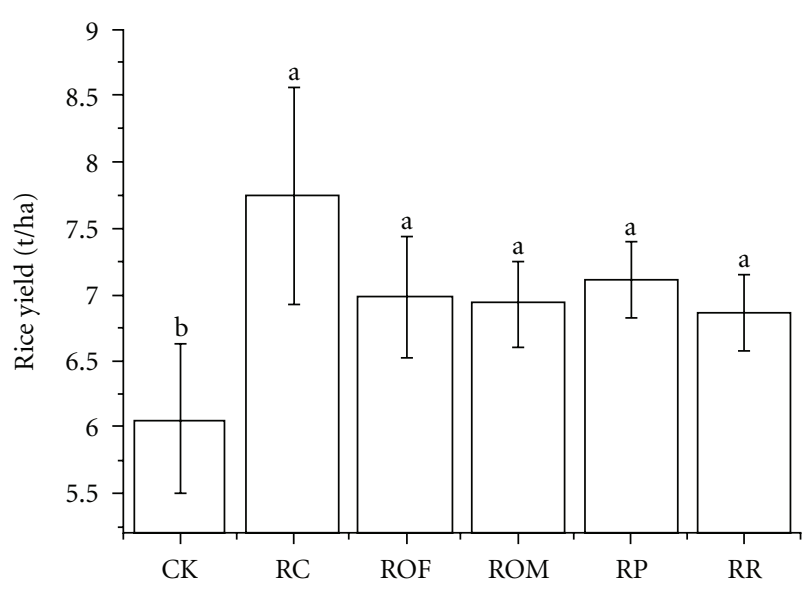

(a)

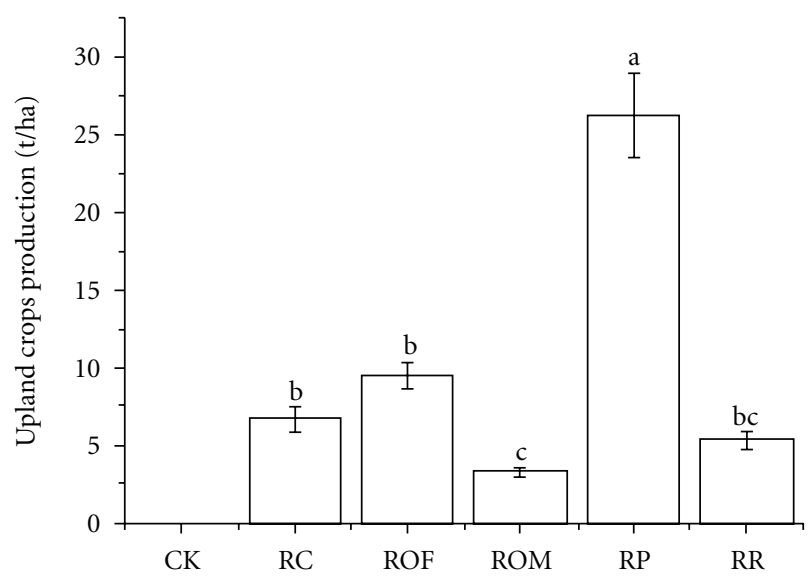

(b)

FIGURE 1: Effect of different paddy-upland crops rotations on the rice yield (a) and upland crops biomass production (b) during 2010-2011. Error bars represent standard deviation, $n=3$. Values followed by different lowercase letters within depth are significantly different between treatment by Tukey's test $(P<0.05)$. Abbreviations: $\mathrm{CK}$, rice-Fallow phase; RR, rice-ryegrass; $\mathrm{RP}$, ricepotato, with rice straw as mulch; $\mathrm{RC}$, rice-Chinese milk vetch; ROM, rice-oilseed rape with burned straw return after harvest; ROF, riceoilseed rape with fresh straw return as mulch at flowering.

$\mathrm{RP}$, and RR decreased in 0-10 $\mathrm{cm}$ depth, but increased in the 10-20 cm depth for ROF and ROM.

For TN and TP, remarkable differences were found between depths, with $0-10 \mathrm{~cm}$ greater than $10-20 \mathrm{~cm}$. The average values of TN/TP were $2.73 / 0.63(\mathrm{~g} / \mathrm{kg})$ in $0-10 \mathrm{~cm}$ and $2.51 / 0.51(\mathrm{~g} / \mathrm{kg})$ in $10-20 \mathrm{~cm}$. However, the difference of available $\mathrm{K}$ between depths was not statistically significant. The rotation effect on soil $\mathrm{TN}, \mathrm{TP}$, and available $\mathrm{K}$ was significant. In comparison with $\mathrm{CK}$, the values of $\mathrm{TN}$ were significantly increased in RC, ROF, and RP in $0-10 \mathrm{~cm}$, with average increments of $18.7 \%, 14.6 \%$, and $20.3 \%$, respectively. However, similar results in $1-20 \mathrm{~cm}$ were only found in RC and RP, with average increments of $10.6 \%$ and $14.4 \%$, respectively. There was a variation of rotation effects on TP in $0-10 \mathrm{~cm}$, with ROF $(0.70 \mathrm{~g} / \mathrm{kg}), \mathrm{RP}(0.72 \mathrm{~g} / \mathrm{kg})$, and
RR $(0.67 \mathrm{~g} / \mathrm{kg})$ significantly greater than CK $(0.53 \mathrm{~g} / \mathrm{kg})$. However, little difference in TP was found in $10-20 \mathrm{~cm}$ depth among all rotations. The available $\mathrm{K}$ was greater in ROF, ROM, and RP compared with CK in $0-10 \mathrm{~cm}$ depth. However, little difference was found among rotations in 10$20 \mathrm{~cm}$ depth, except for ROM, which had the highest value among the six rotations. The rotation effect on soil CEC was variable with soil depth. For $0-10 \mathrm{~cm}$ depth, CEC in RC and ROM was significantly greater than that in $\mathrm{CK}$, but only $\mathrm{RC}$ had significantly different results in 10-20 cm depth.

Soil organic matter (SOM), soil dissolved organic carbon content (DOC), and soil microbial biomass carbon content (MBC) of the six rotations in two soil depths were analyzed and are shown in Table 5. Significant difference was found in SOM between soil depths, with values in $0-10 \mathrm{~cm}$ greater than those in $10-20 \mathrm{~cm}$. SOM of rotations ranged from 18.9$25.8 \mathrm{~g} / \mathrm{kg}$ in $0-10 \mathrm{~cm}$ to $16.6-23.4 \mathrm{~g} / \mathrm{kg}$ in $10-20 \mathrm{~cm}$ depth. Moreover, RP rotation was greater than CK in both depths. However, SOM in ROF and ROM decreased compared with CK in both depths. Small differences for DOC and MBC between depths were found, but the difference among rotations was significant. DOC in CK was the lowest among rotations in both depths. Compared with $\mathrm{CK}, \mathrm{DOC}$ and $\mathrm{MBC}$ increased in RC, RP, and ROF, but decreased in ROM and RP.

\subsection{Diversity of Bacterial Communities in Soils from Different} Paddy-Upland Crop Rotation Systems. Terminal restriction fragment length polymorphism analysis of $16 \mathrm{~S}$ rRNA gene fragments amplified from community DNA was applied to compare the bacterial community structure in the field sites described above. Consistent T-RFLP profiles were obtained from three sampling points of the same field site, as shown by respective replications of the six different rotations (Figure 2).

As shown by cluster analysis, a total of eight rotations formed mainly two major separate branches: pretransplanting (BR) and postharvest (AR) (Figure 3). Within each branch, the lowest similarity was found in CK (followed by $\mathrm{RP}$ ) regardless of sample time, with a mean similarity to others of $62.5 \%$ for BR and $71.3 \%$ for AR. Further, four out of the other five rotations were grouped together with a mean similarity to RP of $69.8 \%$ for BR and $75.8 \%$ for AR. These results indicate remarkable differences in the effect of longterm paddy-upland rotations on soil bacterial community construction.

\section{Discussion}

4.1. Paddy-Upland Crop Rotation Effect on Rice Yield and Upland Crop Biomass Production. Rice yield increased when upland crops were applied during the winter season (Figure 1(a)). The increases were slight but positive, indicating the yield benefit of long-term application of paddyupland crop rotations. Similar results were reported by Ghoshal and Singh [47] and Kim et al. [48]. However, in terms of different agronomic practice, such as upland crop species and the amount of organic and chemical fertilizer input, the magnitudes of these increases were variable. RC 
TABLE 4: Soil chemical properties in $0-10 \mathrm{~cm}$ depth.

\begin{tabular}{|c|c|c|c|c|c|c|}
\hline Depth & Rotation & $\begin{array}{c}\mathrm{pH} \\
\left(1: 2.5 \mathrm{H}_{2} \mathrm{O}\right)\end{array}$ & $\begin{array}{c}\text { Total N } \\
(\mathrm{g} / \mathrm{kg})\end{array}$ & $\begin{array}{l}\text { Total P } \\
(\mathrm{g} / \mathrm{kg}) \\
\end{array}$ & $\begin{array}{c}\text { Available K } \\
(\mathrm{g} / \mathrm{kg})\end{array}$ & $\begin{array}{c}\mathrm{CEC} \\
(\mathrm{Cmol} / \mathrm{kg})\end{array}$ \\
\hline \multirow{6}{*}{$0-10 \mathrm{~cm}$} & $\mathrm{CK}$ & $5.78 \mathrm{a}$ & $2.46 \mathrm{~b}$ & $0.53 \mathrm{~b}$ & $0.25 b$ & $10.73 b$ \\
\hline & $\mathrm{RC}$ & $5.48 \mathrm{~b}$ & $2.92 \mathrm{a}$ & $0.59 b$ & $0.28 \mathrm{ab}$ & $12.23 \mathrm{a}$ \\
\hline & $\mathrm{ROF}$ & $5.21 \mathrm{c}$ & $2.82 \mathrm{a}$ & $0.70 \mathrm{a}$ & $0.30 \mathrm{a}$ & $10.97 b$ \\
\hline & $\mathrm{ROM}$ & $5.64 \mathrm{a}$ & $2.56 b$ & $0.59 \mathrm{~b}$ & $0.33 \mathrm{a}$ & $11.92 \mathrm{a}$ \\
\hline & $\mathrm{RP}$ & $5.15 \mathrm{c}$ & $2.96 a$ & $0.72 \mathrm{a}$ & $0.31 \mathrm{a}$ & $10.80 \mathrm{~b}$ \\
\hline & $\mathrm{RR}$ & $5.40 \mathrm{~b}$ & $2.67 \mathrm{~b}$ & $0.67 \mathrm{a}$ & $0.24 \mathrm{~b}$ & $11.23 \mathrm{~b}$ \\
\hline \multirow{6}{*}{$10-20 \mathrm{~cm}$} & CK & $5.86 \mathrm{~b}$ & $2.36 b$ & 0.47 & $0.22 b$ & $10.26 \mathrm{c}$ \\
\hline & $\mathrm{RC}$ & $5.82 \mathrm{~b}$ & $2.61 \mathrm{ab}$ & 0.49 & $0.23 b$ & $13.50 \mathrm{a}$ \\
\hline & $\mathrm{ROF}$ & $6.00 \mathrm{a}$ & $2.52 b$ & 0.54 & $0.23 b$ & $11.41 \mathrm{~b}$ \\
\hline & $\mathrm{ROM}$ & $5.96 a$ & $2.41 \mathrm{~b}$ & 0.48 & $0.30 \mathrm{a}$ & $11.43 b$ \\
\hline & $\mathrm{RP}$ & $5.84 \mathrm{~b}$ & $2.70 \mathrm{a}$ & 0.53 & $0.25 b$ & $11.01 \mathrm{~b}$ \\
\hline & $\mathrm{RR}$ & $5.89 \mathrm{~b}$ & $2.48 \mathrm{~b}$ & 0.54 & $0.21 b$ & $10.34 c$ \\
\hline \multirow{2}{*}{ Comparison of depth } & $0-10 \mathrm{~cm}$ & $5.44 \mathrm{~b}$ & $2.73 a$ & $0.63 \mathrm{a}$ & 0.29 & 11.31 \\
\hline & $10-20 \mathrm{~cm}$ & $5.90 \mathrm{a}$ & $2.51 \mathrm{~b}$ & $0.51 \mathrm{~b}$ & 0.24 & 11.33 \\
\hline \multirow{3}{*}{ ANOVA } & Rotation & $* *$ & $* *$ & $* *$ & $* *$ & $* *$ \\
\hline & Depth & $* *$ & $* *$ & $* *$ & ns & ns \\
\hline & $\mathrm{R} \times \mathrm{D}$ & * & * & $*$ & $* *$ & $* *$ \\
\hline
\end{tabular}

Means on the same column and for the same sampling time followed by the same letter (or none) are not significantly different at $P<0.05$ by Tukey Test. ns: not significant; ${ }^{*} P<0.05$; ${ }^{*} P<0.01$. Abbreviations: CK: rice-fallow phase; RR: rice-ryegrass; RP: rice-potato, with rice straw as mulch; RC: rice-Chinese milk vetch; ROM: rice-oilseed rape with burned straw return after harvest; ROF: rice-oilseed rape with fresh straw return as mulch at flowering.

TABLE 5: Soil organic carbon content, dissolved organic content, and soil microbial organic content in 0-10 and 10-20 cm depth

\begin{tabular}{|c|c|c|c|c|c|c|}
\hline Rotation & $\begin{array}{l}\text { SOM } \\
(\mathrm{g} / \mathrm{kg})\end{array}$ & $\begin{array}{l}\text { DOC } \\
(\mathrm{g} / \mathrm{kg})\end{array}$ & $\begin{array}{l}\text { MBC } \\
(\mathrm{g} / \mathrm{kg})\end{array}$ & $\begin{array}{l}\text { SOM } \\
(\mathrm{g} / \mathrm{kg})\end{array}$ & $\begin{array}{c}\text { DOC } \\
(\mathrm{mg} / \mathrm{kg})\end{array}$ & $\begin{array}{l}\text { MBC } \\
(\mathrm{g} / \mathrm{kg})\end{array}$ \\
\hline & & $0-10 \mathrm{~cm}$ & & & $10-20 \mathrm{~cm}$ & \\
\hline CK & $21.6 b$ & $0.08 \mathrm{~b}$ & $0.76 b$ & $22.2 \mathrm{ab}$ & $0.07 b$ & $0.64 \mathrm{~b}$ \\
\hline $\mathrm{RC}$ & $25.8 \mathrm{a}$ & $0.16 \mathrm{a}$ & $1.08 \mathrm{a}$ & $21.4 \mathrm{~b}$ & $0.13 \mathrm{a}$ & $1.11 \mathrm{a}$ \\
\hline ROF & $20.3 \mathrm{bc}$ & $0.15 \mathrm{a}$ & $1.22 \mathrm{a}$ & $16.6 \mathrm{c}$ & $0.12 \mathrm{a}$ & $1.08 \mathrm{a}$ \\
\hline ROM & $18.9 c$ & $0.09 b$ & $0.51 b$ & $17.1 \mathrm{c}$ & $0.15 \mathrm{a}$ & $0.44 \mathrm{~b}$ \\
\hline $\mathrm{RP}$ & $23.7 \mathrm{a}$ & $0.20 \mathrm{a}$ & $0.57 b$ & $23.4 \mathrm{a}$ & $0.08 b$ & $0.60 \mathrm{~b}$ \\
\hline $\mathrm{RR}$ & $21.3 \mathrm{~b}$ & $0.19 \mathrm{a}$ & $1.09 \mathrm{a}$ & $18.6 \mathrm{c}$ & $0.14 \mathrm{a}$ & $1.04 \mathrm{a}$ \\
\hline \multicolumn{7}{|c|}{ Comparison of depth } \\
\hline $0-10 \mathrm{~cm}$ & $21.93 a$ & 0.15 & 0.87 & & & \\
\hline $10-20 \mathrm{~cm}$ & $19.88 \mathrm{~b}$ & 0.11 & 0.82 & & & \\
\hline \multicolumn{7}{|l|}{ ANOVA } \\
\hline Rotation & $* *$ & $* *$ & $* *$ & & & \\
\hline Depth & $* *$ & ns & ns & & & \\
\hline $\mathrm{R} \times \mathrm{D}$ & $* *$ & $* *$ & $* *$ & & & \\
\hline
\end{tabular}

Means on the same column and for the same sampling time followed by the same letter (or none) are not significantly different at $P<0.05$ by Tukey Test; ns: not significant; ${ }^{*} P<0.05 ;{ }^{*} P<0.01$. Abbreviations: CK: rice-fallow phase; RR: rice-ryegrass; RP: rice-potato, with rice straw as mulch; RC: rice-Chinese milk vetch; ROM: rice-oilseed rape with burned straw return after harvest; ROF: rice-oilseed rape with fresh straw return as mulch at flowering.

had the highest average yield of $7.74 \mathrm{t} / \mathrm{ha}$, which was $27.8 \%$ higher than CK. The yield increase might be attributed to the high nitrogen fix capabilities and biomass accumulation in $\mathrm{RC}[49,50]$ However, the capacity of green manure to sufficiently supply soil nutrients is still variable and depends on biomass production and soil management. Slight increases were found in RR, RP, ROM, and ROF compared with $\mathrm{CK}$, although the differences were not statistically significant. The rotation of rice-potato produced the highest biomass production, followed by ryegrass, rapeseed, and Chinese milk vetch (Figure 1). However, considering the harvest of RR for pasture and the burned straw of ROM, the amount of plant residues returned to the soil was limited. Therefore, only three rotations of RP, RC, and ROF had the organic material returned. RP had the highest value of returned organic material, but the yield improvement 


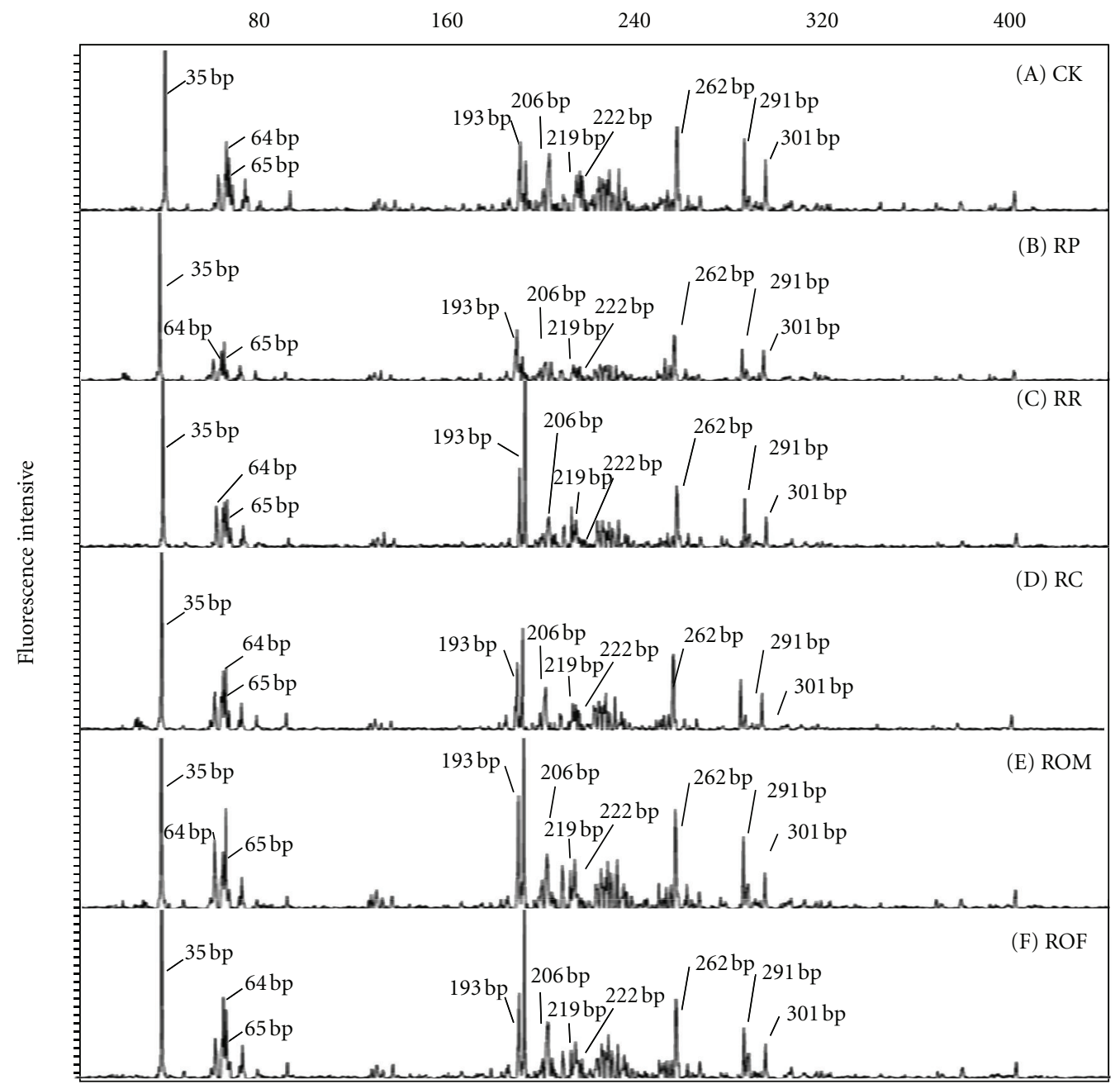

FIGURE 2: Terminal restriction fragment length polymorphism profiles of soil bacterial communities derived from six different rotation fields before transplanting (BR): CK (rice-fallow phase), RR (rice-ryegrass), RP (rice-potato, with rice straw as mulch), RC (rice-Chinese milk vetch), ROM (rice-oilseed rape with burned straw return after harvest), and ROF (rice-oilseed rape with fresh straw return as mulch at flowering) are shown. Terminal fragments were generated by a HaeIII digestion of $16 \mathrm{~S}$ rRNA gene fragments amplified from total community DNA. Selected terminal restriction fragments differing in their relative abundance between the studied sites are indicated.

was limited. Ghoshal and Singh [47] suggested that crop biomass and grain yield were improved when straw was returned. However, Henderson [51] remarked that most of the studies did not provide an insight into how the procedure influenced crop yield. The results obtained were often siteand year-specific and often contradictory and inconclusive due to variability in soil type, cropping systems, and climate $[52,53]$. Therefore, further research is needed to investigate the influence of organic return on rice yield in different paddy-upland rotations.

4.2. Paddy-Upland Crop Rotation Effects on Soil Quality Attributes. In paddy-upland crop rotations, soil puddling in advance of transplanting can foster high productivity [54]. This procedure involves plowing the soil when wet, puddling it, and keeping the area flooded for the duration of rice growth. Puddling breaks down and disperses soil aggregates into microaggregates and individual particles [12]. However, continuous use of this method of rice cropping will destroy soil structure and create a poor physical condition [13, 14]. In this study, RC and RP improved the soil MWD compared to $\mathrm{CK}$. In addition, RC and ROF increased the soil bulk density compared with CK (Table 3 ). These results suggest that rice rotated with milk vetch might improve the paddy soil structure by increasing the soil MWD.

Significant soil chemical quality diversity was found among rotations. Soil $\mathrm{pH}$ value was acid in the paddy field, which was consistent in our results. Application of ROM increased the $\mathrm{pH}$ value as well as available $\mathrm{K}$ compared with CK. This might be due to the use of rapeseed straw burned into ash and applied as fertilizer. Biomass ash is considered as a potassium fertilizer in China. Furthermore, improved TN and SOM were found in RC and RP. The positive relationship between yield and TN and SOM might provide the evidence for the positive effect of RC rotation on rice yield. 


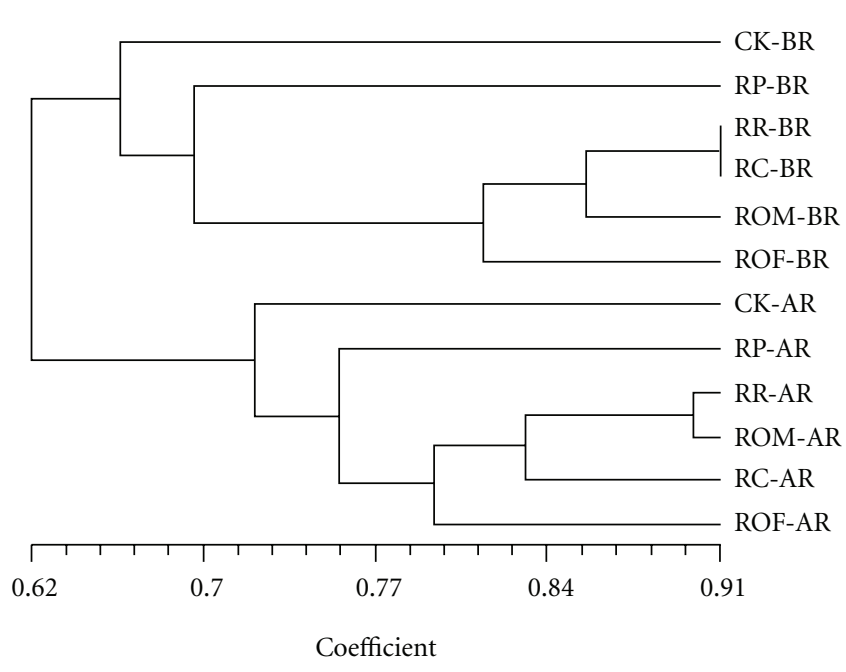

FIGURE 3: UPGMA dendrogram generated from all representative T-RFLP sample profiles. The scale indicated the coefficient between soil from paddy-upland crop rotation systems sampled at postharvest $(A R)$ and pretransplanting (BR); Abbreviations: $C K$, rice-fallow phase; RR, rice-ryegrass; $\mathrm{RP}$, rice-potato, with rice straw as mulch; $\mathrm{RC}$, rice-Chinese milk vetch; $\mathrm{ROM}$, rice-oilseed rape with burned straw return after harvest; ROF, rice-oilseed rape with fresh straw return as mulch at flowering.

Soil quality is different for different crop species [55-57] as well as the proper management of crop residues in terms of improving soil organic matter dynamics and nutrient cycling $[58,59]$. In our experiment, soil quality was influenced by both crop species and residue management, and the integrated results were shown by soil quality indicators. Green manure crop (milk vetch) cultivation of upland plant species during the fallow seasons in the monorice cultivation system was found to improve soil fertility because of its higher nitrogen fixing capabilities and rapid biomass accumulation characteristics $[49,50]$ We found that MWD, TN, CEC, SOM, DOC, and MBC improved in rice-milk vetch rotations compared with CK. However, increased bulk density was also found in the rice-milk vetch rotation; this has a generally negative effect on soil quality. Rapeseed and winter rye can be sown after rice and harvested before rice transplanting. These systems can maximize benefits of the rotation as well as availability and resources [60]. Brassica species are important oil seed crops in China and can aid in controlling pests and weeds because of the allelochemicals they release. In this study, two different rapeseed agronomic practices were introduced in terms of different harvest dates. Unlike the regular harvest practice for oil seed, the rapeseed was harvested artificially at flowering, when its glucosinolate content is relatively high $[61,62]$. In addition, rapeseed also has potential for use as a green manure crop, which may prevent soil erosion and reclaim leachable nutrients [63, 64]. We found that ROM and ROF had the most soil CEC, TP, and available $\mathrm{K}$ in $10-20 \mathrm{~cm}$ depth (Table 4) and that ROF has the highest value of all the rotations in MBC in $10-20 \mathrm{~cm}$ depth (Table 5).
4.3. Paddy-Upland Crop Rotations on Soil Bacterial Communities' Diversity. Soil bacterial communities were significantly affected by soil type and plant species as well as environmental factors. As shown in Figure 3, two major separate branches were found among eight rotations: pretransplanting (BR) and postharvest (AR). Within rotations, CK was totally different from the others; it had the lowest similarity value regardless of sample time, with a mean similarity of $62.5 \%$ at BR and $71.3 \%$ at AR to others. Further, four out of the other five rotations were grouped together with a mean similarity to RP of $69.8 \%$ at BR and $75.8 \%$ at AR. These results indicate remarkably different long-term paddy-upland rotation effects on soil bacterial community construction. However, further analysis is needed to explore the details of these bacterial communities.

\section{Conclusions}

Significant differences in soil chemicals (i.e., soil $\mathrm{pH}, \mathrm{TN}$, CEC, SOM, and MBC), physical properties (soil bulk density), and soil bacterial communities were detected between cropping seasons within the year (rice and upland crops season), irrespective of different winter upland crop species. Rice-Chinese milk vetch and rice-rapeseed rotations improved the soil quality to some extent, which might result in the greatest yield performance in rice-Chinese milk vetch rotations among the tested rotations. Soil bacterial communities in $\mathrm{CK}$ and $\mathrm{RP}$ were remarkably different from those in the other rotations according to the T-RFLP of $16 \mathrm{~S}$ rRNA genes.

\section{Acknowledgments}

This research was supported by grants from the "Fivetwelfth" National Science and Technology Support Program (2011BAD16B14) and the National Natural Science Foundation of China (31171502).

\section{References}

[1] K. G. Cassman, S. K. De Datta, D. C. Olk et al., "Yield decline and the nitrogen economy of long-term experiments on continuous, irrigated rice systems in the tropics," in Soil Management, Experimental Basis For Sustainability and Environmental Quality, R. Lal and B. A. Stewart, Eds., pp. 181222, Lewis, CRC, Boca Raton, Fla, USA, 1995.

[2] A. Dobermann and C. Witt, "The potential impact of crop intensification on carbon and nitrogen cycling in intensive rice systems," in Carbon and Nitrogen Dynamics in Flooded Soils, G. D. Kirk and D. Olk, Eds., pp. 1-25, International Rice Research Institute, Laguna, Philippines, 2000.

[3] K. Yanagisawa and Y. Muramatsu, "Transfer of technetium from soil to paddy and upland rice," Journal of Radiation Research, vol. 36, no. 3, pp. 171-178, 1995.

[4] C. Witt, K. G. Cassman, D. C. Olk et al., "Crop rotation and residue management effects on carbon sequestration, nitrogen cycling and productivity of irrigated rice systems," Plant and Soil, vol. 225, no. 1-2, pp. 263-278, 2000.

[5] S. W. Chang Chien, M. C. Wang, J. H. Hsu, and K. Seshaiah, "Influence of fertilizers applied to a paddy-upland rotation on 
characteristics of soil organic carbon and humic acids," Journal of Agricultural and Food Chemistry, vol. 54, no. 18, pp. 6790 6799, 2006.

[6] S. Nishimura, S. Yonemura, T. Sawamoto et al., "Effect of land use change from paddy rice cultivation to upland crop cultivation on soil carbon budget of a cropland in Japan," Agriculture, Ecosystems and Environment, vol. 125, no. 1-4, pp. 9-20, 2008.

[7] S. Huang, W. Y. Rui, X. X. Peng, W. R. Liu, and W. J. Zhang, "Responses of soil organic carbon content and fractions to land-use conversion from paddy field to upland," Chinese Journal of Environmental Science, vol. 30, no. 4, pp. 1146-1151, 2009.

[8] N. Yamaguchi, A. Kawasaki, and I. Iiyama, "Distribution of uranium in soil components of agricultural fields after longterm application of phosphate fertilizers," Science of the Total Environment, vol. 407, no. 4, pp. 1383-1390, 2009.

[9] C. K. Li, Paddy Soils of China, Science Press, Beijing, China, 1992.

[10] D. T. Xie and S. L. Chen, Theory and Technique of Paddy Field Under Soil Virginization, Southwest Normal University Press, Chongqing, China, 2002.

[11] L. Qunhua, K. Xin, C. Changzhi et al., "New irrigation methods sustain malaria control in Sichuan Province, China," Acta Tropica, vol. 89, no. 2, pp. 241-247, 2004.

[12] G. Kirchhof, H. B. So, T. Adisarwanto et al., "Growth and yield response of grain legumes to different soil management practices after rainfed lowland rice," Soil and Tillage Research, vol. 56, no. 1-2, pp. 51-66, 2000.

[13] B. S. Boparai, Yadvinder-Singh, and B. D. Sharma, "Effect of green manuring with Sesbania aculeata on physical properties of soil and on growth of wheat in rice-wheat and maize-wheat cropping systems in a semiarid region of India," Arid Soil Research \& Rehabilitation, vol. 6, no. 2, pp. 135-143, 1992.

[14] M. Mohanty and D. K. Painuli, "Land preparatory tillage effect on soil physical environment and growth and yield of rice in a Vertisol," Journal of the Indian Society of Soil Science, vol. 51, no. 3, pp. 223-228, 2004.

[15] E. G. Gregorich, C. M. Monreal, M. R. Carter, D. A. Angers, and B. H. Ellert, "Towards a minimum data set to assess soil organic matter quality in agricultural soils," Canadian Journal of Soil Science, vol. 74, no. 4, pp. 367-385, 1994.

[16] I. Hussain, K. R. Olson, M. M. Wander, and D. L. Karlen, "Adaptation of soil quality indices and application to three tillage systems in Southern Illinois," Soil and Tillage Research, vol. 50, no. 3-4, pp. 237-249, 1999.

[17] J. W. Doran and M. R. Zeiss, "Soil health and sustainability: managing the biotic component of soil quality," Applied Soil Ecology, vol. 15, no. 1, pp. 3-11, 2000.

[18] J. M. Tisdall and J. M. Oades, "Organic matter and waterstable aggregates in soils," Journal of Soil Science, vol. 33, no. 2, pp. 141-163, 1982.

[19] G. J. Churchman and K. R. Tate, "Stability of aggregates of different size grades in allophanic soils from volcanic ash in New Zealand," Journal of Soil Science, vol. 38, no. 1, pp. 19-27, 1987.

[20] C. A. Campbell and R. P. Zentner, "Soil organic matter as influenced by crop rotations and fertilization," Soil Science Society of America Journal, vol. 57, no. 4, pp. 1034-1040, 1993.

[21] M. A. Arshad and G. M. Coen, "Characterization of soil quality: physical and chemical criteria," American Journal of Alternative Agriculture, vol. 7, no. 1-2, pp. 25-31, 1992.

[22] B. Giri, P. H. Giang, R. Kumari, R. Prasad, and A. Varma, "Microbial diversity in soils," in Micro-Organisms in Soils,
Roles in Genesis and Functions, F. Buscot and S. Varma, Eds., pp. 195-212, Springer, Heidelberg, Germany, 2005.

[23] H. P. Bais, T. L. Weir, L. G. Perry, S. Gilroy, and J. M. Vivanco, "The role of root exudates in rhizosphere interactions with plants and other organisms," Annual Review of Plant Biology, vol. 57, pp. 233-266, 2006.

[24] B. Prithiviraj, M. W. Paschke, and J. M. Vivanco, "Root communication, the role of root exudates," Encyclopedia of Plant and Crop Science, vol. 1, pp. 1-4, 2007.

[25] L. Innes, P. J. Hobbs, and R. D. Bardgett, "The impacts of individual plant species on rhizosphere microbial communities in soils of different fertility," Biology and Fertility of Soils, vol. 40, no. 1, pp. 7-13, 2004.

[26] K. M. Batten, K. M. Scow, K. F. Davies, and S. P. Harrison, "Two invasive plants alter soil microbial community composition in serpentine grasslands," Biological Invasions, vol. 8, no. 2, pp. 217-230, 2006.

[27] A. C. Kennedy and K. L. Smith, "Soil microbial diversity and the sustainability of agricultural soils," Plant and Soil, vol. 170, no. 1, pp. 75-86, 1995.

[28] K. E. Giller, M. H. Beare, P. Lavelle, A. M. N. Izac, and M. J. Swift, "Agricultural intensification, soil biodiversity and agroecosystem function," Applied Soil Ecology, vol. 6, no. 1, pp. 3-16, 1997.

[29] M. J. Swift and J. M. Anderson, "Biodiversity and ecosystem function in agricultural systems," Biodiversity and Ecosystem Function, vol. 99, no. 6, pp. 15-41, 1993.

[30] R. G. Joergensen and F. Wichern, "Quantitative assessment of the fungal contribution to microbial tissue in soil," Soil Biology and Biochemistry, vol. 40, no. 12, pp. 2977-2991, 2008.

[31] L. Rukun, Zheng, and S. Jian S, "Nutrient balance of agroecosystem in six provinces in Southern China," Scientia Agricultura Sinica, vol. 33, no. 2, pp. 63-67, 2000.

[32] Q. Yusheng, T. Shihua, F. Wenqiang, and S. Xifa, "Spatial variability of soil nutrient characteristics under paddy-upland crop rotation in chengdu plain," Acta Pedologica Sinica, vol. 45, no. 2, pp. 354-359, 2008.

[33] H. Chu, S. Morimoto, T. Fujii, K. Yagi, and S. Nishimura, "Soil ammonia-oxidizing bacterial communities in paddy rice fields as affected by upland conversion history," Soil Science Society of America Journal, vol. 73, no. 6, pp. 2026-2031, 2009.

[34] Z. Gong, G. Zhang, and G. Luo, "Versify of Anthrosols in China," Pedosphere. 9, 1999.

[35] S. S. Staff, Keys To Soil Taxonomy, U.S.D. A Soil Conservation Service, Blacksburg, Va, USA, 7th edition, 1996.

[36] G. Fu, D. Wang, C. Xu, and X. Zhang, "Effect of winter conservation tillage in paddy field on soil enzyme activities and grain quality," Plant Nutrition and Fertilizer Science, vol. 15, no. 3, pp. 618-624, 2009.

[37] R. L. Parfitt, C. Ross, L. A. Schipper, J. J. Claydon, W. T. Baisden, and G. Arnold, "Correcting bulk density measurements made with driving hammer equipment," Geoderma, vol. 157, no. 1-2, pp. 46-50, 2010.

[38] J. Six, K. Paustian, E. T. Elliott, and C. Combrink, "Soil structure and organic matter: I. Distribution of aggregate-size classes and aggregate-associated carbon," Soil Science Society of America Journal, vol. 64, no. 2, pp. 681-689, 2000.

[39] W. H. Hendershot, H. Lalande, and M. Duquette, "Ion exchange and exchangeable cations," in Soil Sampling and Methods of Analysis, M. R. Carter, Ed., pp. 167-175, Lewis, Boca Raton, Fla, USA, 1993.

[40] J. M. Bremner and C. S. Mulvaney, "Nitrogen-total," in Methods of Soil Analysis, Agronomy Monograph 9, Part 2, pp. 
595-624, American Society of Agronomy, Madison, Wis, USA, 2nd edition, 1982.

[41] G. P. Sparling, K. N. Whale, and A. J. Ramsay, "Quantifying the contribution from the soil microbial biomass to the extractable P levels of fresh and air-dried soils," Australian Journal of Soil Research, vol. 23, no. 4, pp. 613-621, 1985.

[42] D. Nelson and L. Sommers, "Total carbon, organic carbon and organic matter," in Methods of Soil Analysis SSSA Book, Series No. 7. SSSA, Part 2, pp. 539-579, SSSA, Madison, Wis, USA, 1996.

[43] E. D. Vance, P. C. Brookes, and D. S. Jenkinson, "Microbial biomass measurements in forest soils: the use of the chloroform fumigation-incubation method in strongly acid soils," Soil Biology and Biochemistry, vol. 19, no. 6, pp. 697-702, 1987.

[44] J. Zhou, M. A. Bruns, and J. M. Tiedje, "DNA recovery from soils of diverse composition," Applied and Environmental Microbiology, vol. 62, no. 2, pp. 316-322, 1996.

[45] W. T. Liu, T. L. Marsh, H. Cheng, and L. J. Forney, "Characterization of microbial diversity by determining terminal restriction fragment length polymorphisms of genes encoding 16S rRNA," Applied and Environmental Microbiology, vol. 63, no. 11, pp. 4516-4522, 1997.

[46] J. Dunbar, L. O. Ticknor, and C. R. Kuske, "Phylogenetic specificity and reproducibility and new method for analysis of terminal restriction fragment profiles of 16S rRNA genes from bacterial communities," Applied and Environmental Microbiology, vol. 67, no. 1, pp. 190-197, 2001.

[47] N. Ghoshal and K. P. Singh, "Effects of farmyard manure and inorganic fertilizer on the dynamics of soil microbial biomass in a tropical dryland agroecosystem," Biology and Fertility of Soils, vol. 19, no. 2-3, pp. 231-238, 1995.

[48] S. Y. Kim, S. H. Oh, W. H. Hwang, K. Y. Choi, and B. G. Oh, "Optimum soil incorporation time of Chinese milk vetch (Astralagus sinicus L.) for its natural re-seeding and green manuring of rice in Gyeongnam province Korea," Journal of Crop Science and Biotechnology, vol. 11, pp. 193-198, 2008.

[49] N. K. Fageria, "Green manuring in crop production," Journal of Plant Nutrition, vol. 30, no. 5, pp. 691-719, 2007.

[50] C. H. Lee, K. D. Park, K. Y. Jung et al., "Effect of Chinese milk vetch (Astragalus sinicus L.) as a green manure on rice productivity and methane emission in paddy soil," Agriculture, Ecosystems and Environment, vol. 138, no. 3-4, pp. 343-347, 2010.

[51] D. W. Henderson, "Soil water management in semiarid environments," in Agriculture in the Semi Arid Environments, A. E. Hall, G. H. Cannel, and H. W. Lawton, Eds., pp. 225237, Springer, Berlin, Germany, 1979.

[52] C. J. Wright and D. C. Coleman, "The effects of disturbance events on labile phosphorus fractions and total organic phosphorus in the Southern Appalachians," Soil Science, vol. 164, no. 6, pp. 391-402, 1999.

[53] A. C. Guzha, "Effects of tillage on soil microrelief, surface depression storage and soil water storage," Soil and Tillage Research, vol. 76, no. 2, pp. 105-114, 2004.

[54] S. Singh, S. N. Sharma, and R. Prasad, "The effect of seeding and tillage methods on productivity of rice-wheat cropping system," Soil and Tillage Research, vol. 61, no. 3-4, pp. 125$131,2001$.

[55] D. L. Karlen, N. S. Eash, and P. W. Unger, "Soil and crop management effects on soil quality indicators," American Journal of Alternative Agriculture, vol. 7, no. 1-2, pp. 48-55, 1992.

[56] C. A. Campbell, V. O. Biederbeck, B. G. McConkey, D. Curtin, and R. P. Zentner, "Soil quality-effect of tillage and fallow frequency. Soil organic matter quality as influenced by tillage and fallow frequency in a silt loam in Southwestern Saskatchewan," Soil Biology and Biochemistry, vol. 31, no. 1, pp. 1-7, 1999.

[57] A. D. Halvorson, B. J. Wienhold, and A. L. Black, "Tillage, nitrogen, and cropping system effects on soil carbon sequestration," Soil Science Society of America Journal, vol. 66, no. 3, pp. 906-912, 2002.

[58] J. T. Spargo, M. A. Cavigelli, S. B. Mirsky, J. E. Maul, and J. J. Meisinger, "Mineralizable soil nitrogen and labile soil organic matter in diverse long-term cropping systems," Nutrient Cycling in Agroecosystems, vol. 90, no. 2, pp. 253-266, 2011.

[59] R. Lal, "Challenges and opportunities in soil organic matter research," European Journal of Soil Science, vol. 60, no. 2, pp. 158-169, 2009.

[60] A. Clark, Managing Cover Crops Profitably, Handbook Series Book 9, Sustainable Agriculture Network, 3rd edition, 2007.

[61] S. Millán, M. C. Sampedro, P. Gallejones et al., "Identification and quantification of glucosinolates in rapeseed using liquid chromatography-ion trap mass spectrometry," Analytical and Bioanalytical Chemistry, vol. 394, no. 6, pp. 1661-1669, 2009.

[62] S. Yasumoto, M. Matsuzaki, H. Hirokane, and K. Okada, "Glucosinolate content in rapeseed in relation to suppression of subsequent crop," Plant Production Science, vol. 13, no. 2, pp. 150-155, 2010.

[63] B. S. Choi, K. C. Hong, J. J. Nam et al., "Effect of rapeseed (Brassica napus) incorporated as green manure on weed growth in rice paddy, a pot experiment," Korean Journal of Weed Science, vol. 29, no. 1, pp. 39-45, 2009.

[64] E. Bernard, R. P. Larkin, S. Tavantzis et al., "Compost, rapeseed rotation, and biocontrol agents significantly impact soil microbial communities in organic and conventional potato production systems," Applied Soil Ecology, vol. 52, pp. 29-41, 2012. 

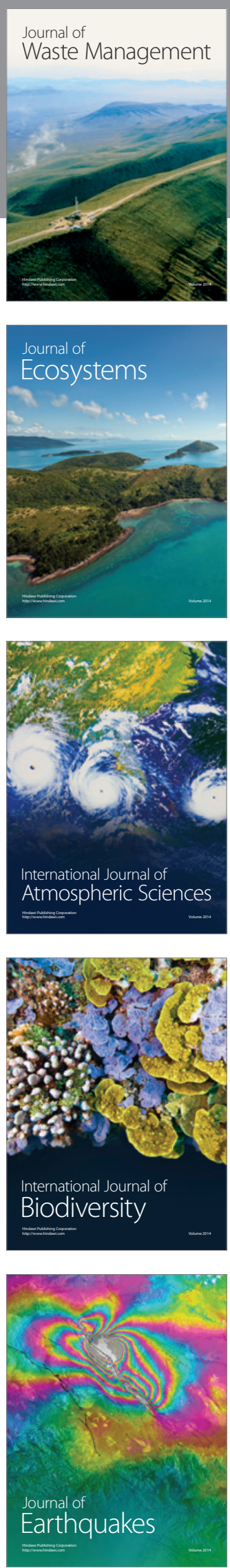
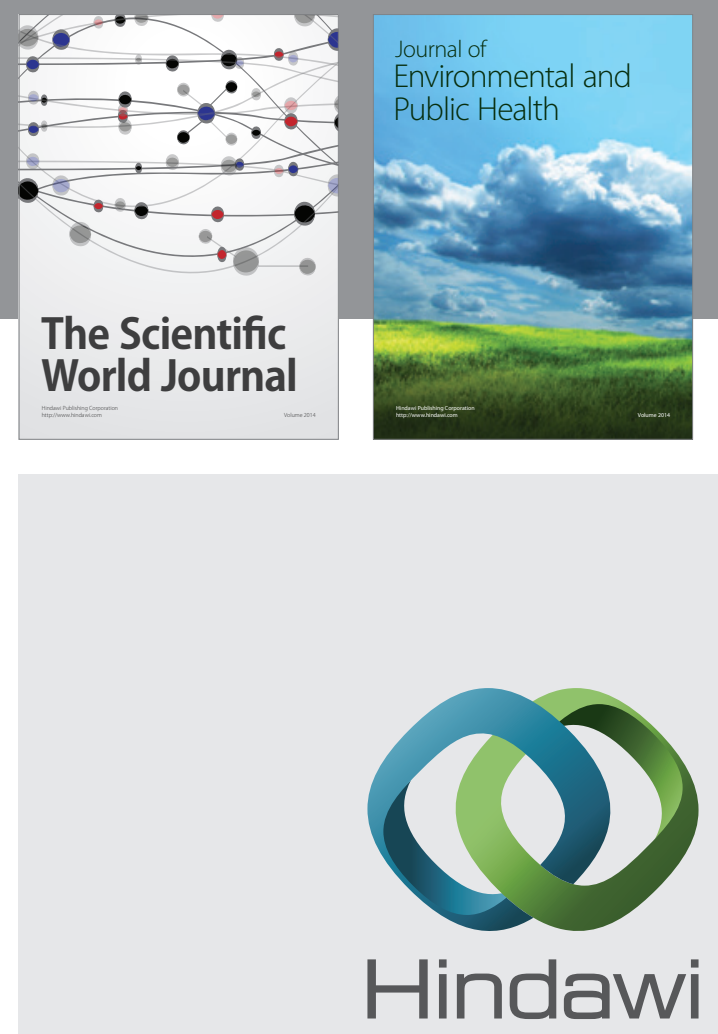

Submit your manuscripts at

http://www.hindawi.com
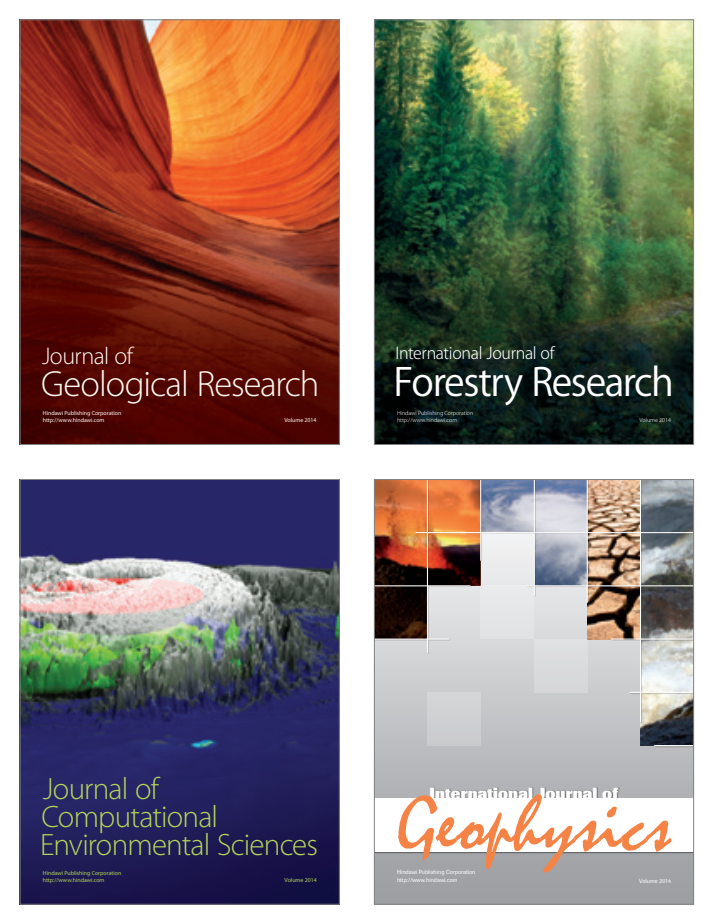
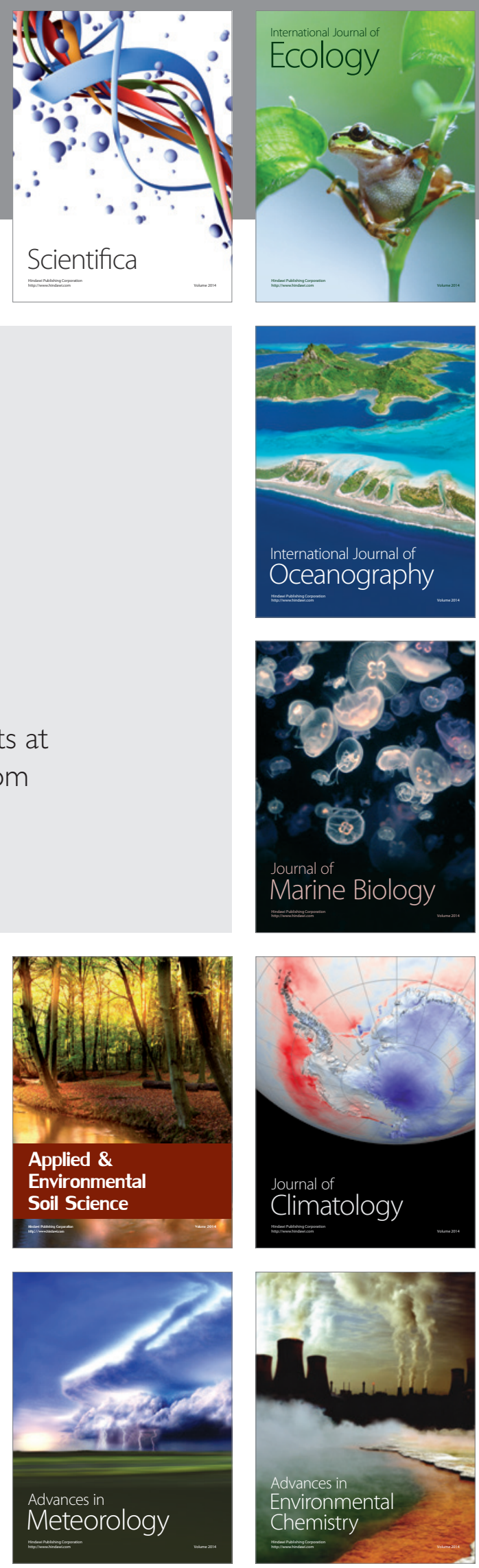